\title{
Anything but Race: Avoiding Racial Discourse to Avoid Hurting You or Me
}

\author{
Phillip Atiba Goff ${ }^{1}$, Matthew Christian Jackson ${ }^{1}$, Andrew H. Nichols ${ }^{2}$, \\ Brooke Allison Lewis Di Leone ${ }^{3}$ \\ ${ }^{1}$ The University of California, Los Angeles, USA \\ ${ }^{2}$ National Center for Post-Traumatic Stress Disorder, Boston, USA \\ ${ }^{3}$ Maryland Higher Education Commission, Baltimore, USA \\ Email: goff@psych.ucla.edu
}

Received December 21 $1^{\text {st }}, 2012$; revised January $23^{\text {rd }}, 2013$; accepted February $24^{\text {th }}, 2013$

\begin{abstract}
The present research examines how Whites employ strategic colorblindness - the strategic assertion that race should not and/or does not matter - in interracial interactions, and how stereotype threat and concern about non-Whites influence the use of this conversational technique. Because colorblindness can be egalitarian or anti-egalitarian (Knowles, Lowery, Hogan, \& Chow, 2009), one must define colorblindness in order to understand how it is employed. Two studies provide evidence that both concerns that racial categorization harms non-Whites and concerns with appearing racist affects the use of strategic colorblindness. Study 1 uses field observations to explore the content of spontaneous colorblind statements and their relationship to stereotype threat. Study 2 manipulates stereotype threat and concerns for non-Whites, revealing that each independently increases Whites' endorsement of strategic colorblindness relative to control conditions. This research highlights the importance of both studying interracial interactions in field settings and considering how definitions of diversity shape intergroup contexts.
\end{abstract}

Keywords: Stereotype Threat; Interracial Interactions; Intergroup Processes

\section{Introduction}

"You know, like King said: color shouldn't matter so don't, like, pay any attention to it."-Study 1, Participant 73

It is often good advice to avoid talking about controversial topics. We are admonished to avoiding talking about politics or religion over casual dinners, and to eschew painful family stories during the holidays. It should not be surprising, then, that the controversial topic of race causes many to feel anxious (Richeson \& Shelton, 2007, Vorauer, Main, \& O'Connell, 1998; Vorauer, Hunter, Main, \& Roy, 2000) and subsequently, to avoid the topic all together (Apfelbaum, Norton, \& Sommers, 2008; Goff, Steele, \& Davies, 2008). An emerging consensus in research on interracial interactions reveals that this response is particularly true for dominant group members, usually Whites. Unfortunately, this literature also finds that avoiding the topic and the attendant anxiety around it can be counterproductive, creating inefficient interactions at best (Apfelbaum et al., 2008) and even the ironic suspicion among non-Whites that avoidant Whites are racist (Apfelbaum et al., 2008; Richeson \& Shelton, 2007; Dovidio, Kawakami, \& Gaertner, 2002).

Apfelbaum and colleagues refer to avoiding the topic of race as "strategic colorblindness," and suggest that it stems from Whites' concern with appearing prejudiced (Apfelbaum et al., 2008). Apfelbaum and colleagues argue that, by avoiding the topic of race, Whites may believe that they need not fear accusations of racism. But given that colorblindness is often perceived as a hierarchy-enhancing ideology, one designed to forbid the consideration of race for the purposes of creating intergroup equality (Knowles et al., 2009), why would individuals believe employing colorblindness would protect them from ac- cusations of racism?

Perhaps the answer depends on how Whites believe colorblindness affects non-Whites? Research by Knowles and colleagues suggests that, while some perceive colorblindness as a procedural ideology, designed to enhance hierarchies, some see it as a distributive ideology, designed to protect non-Whites from the negative consequences of discrimination. This distributive colorblindness, historians argue, is consistent with Martin Luther King, Jr.'s "colorblindness" and seen as an egalitarian principle (Carson, 1987). The possibility that strategic colorblindness could be a response to egalitarian impulses is not explored in previous research on strategic colorblindness and leaves us with the outstanding question: does strategic colorblindness stem from concerns about the self, concerns about others, or both? The present research is designed to answer this question.

We expect that both concerns with appearing prejudiced and concerns with how categorization affects non-Whites will influence the use of strategic colorblindness. Specifically, the presence of either concern may be sufficient to produce either spontaneous colorblind utterances or endorsement of strategic colorblindness. If confirmed, this would suggest that, much like other uncomfortable topics, regardless of whether one's concerns center around one's self or someone else, the most obvious way to avoid injury is to avoid the topic. However, it would also suggest that, unlike previous research, understanding the motivation of an individual that employs strategic colorblindness may be crucial for modifying the behavior.

In addition to this fundamental question, the present research attempts to augment the literature on strategic colorblindness in two additional ways: integrating stereotype threat theory into the application of strategic colorblindness and examining spon- 
taneous strategic colorblindness in naturalistic conversations about race. With regard to the first, the literature on strategic colorblindness is couched in terms of concerns with appearing prejudiced, this concerns has not been framed in terms of stereotype threat - the concern with conforming to or being evaluated in terms of a negative stereotype about ones group (Goff, Steele, \& Davies, 2008; Steele, 1997). Stereotype threat often leads to performance decrements either through cognitive load (Schmader \& Johns, 2003) or simply anxiety (Goff et al., 2008). However, scholars traditionally use stereotype threat to frame educational outcomes, and tend to focus on stigmatized group members. A growing literature establishes that Whites can and do experience stereotype threat around appearing prejudiced, and can even access that experience consciously (Frantz, Cuddy, Burnett, Ray, \& Hart, 2004; Goff et al., 2008). Consequently, the present research measures and manipulates stereotype threat for Whites with the aim of expanding the traditional conceptualization - and application - of the theory.

With regards to the second, we use actual group conversations about race to examine the prevalence of comments that communicate colorblindness, providing applied evidence for the previously laboratory phenomena. Taken together, the present research provides an important translation of strategic colorblindness to actual conversations and clarifies the motivations of dominant group members as they engage in intergroup interactions.

\section{Overview of Research}

Our efforts to expand and apply the literature on strategic colorblindness took the form of two studies. Study 1 examined real world conversations about race to determine whether or not individuals spontaneously engaged in strategic colorblindness in mixed-race context more often than in same-race contexts. Previous research suggests that the mere presence of outgroup members is enough to provoke stereotype threat (Inzlicht \& Ben-Zeev, 2000). Consequently, because we expected that stereotype threat would produce spontaneous strategically colorblind comments, we expected more of these utterances in mixedrace contexts than same-race ones. Evidence that stereotype threat produces strategic colorblindness would then allow us to test potentially competing hypotheses: that either stereotype threat or concerns for outgroup members prompt Whites to endorse strategic colorblindness.

To test these potential motivations, Study 2 manipulates stereotype threat and information about the harms that categorizing non-Whites in terms of race produce. Again, we expected that, either when Whites were concerned with appearing prejudiced or when they were concerned that race-consciousness would harm non-Whites, they would be more likely to endorse strategic colorblindness.

\section{Study 1}

Study 1 was designed to identify the language Whites use when discussing race in interracial and same-race groups and to assess whether or not this language maps on to the concept of "strategic colorblindness." During group conversations, we counted the number of comments made about race in the following three ways: paying attention to race is negative, categorizing people by race is uncomfortable, and categorizing people by race hurts those who are categorized - each an explicit articulation of strategic colorblindness. Study 1 tests whether
Whites will employ explicit colorblind strategies in interracial interactions, devaluing race-consciousness to the extent that non-Whites are present.

\section{Method}

\section{Participants and Design}

A total of 214 American undergraduate participants (116 women \& 98 men; 182 White \& 32 Black) at a large public university in the US participated in 28 conversation groups ranging in size from of 5 to 11 people. Groups contained either White participants only ( 8 groups) or White and non-White participants (20 groups) creating our two-cell design. Participants came to the laboratory in order to participate in a student run roundtable discussion called the Race Relations Project (RRP). Participants were part of an optional summer preparatory program for incoming students and were randomly assigned to discussion groups by the project coordinators. Students were offered extra credit in their summer classes as compensation for participation. The stated purpose of the 90-minute conversations was to provide an open forum for university students to discuss racial issues. Student facilitators led discussions, and were trained to have minimal involvement in the conversations. All conversations were videotaped. Four independent raters coded the videos of the 28 conversations for comments about race.

Video coders were instructed to count all comments that mentioned race in three ways. First, they were to count all comments that said that paying attention to race was negative. Comments included:

"Really, why does it even matter? We shouldn't even care whether someone is Black or White or Pink or Purple or whatever. Paying attention to it makes it worse."

and

'I don't think people really even notice anymore, which is a good thing. Like, who wants to be 'White,' or whatever? I'm a person. You're a person. Just, you know, treat people like they're people; like human beings."

Second, coders were asked to count the number of comments that explicitly mentioned that categorizing individuals by race was uncomfortable, an explicit indication of stereotype threat. Comments included:

"Like, which one is it? Black or African American or what? It seems like it's just easier not to do the label thing at all, right?" and

"I don't like labeling people by their race."

Finally, coders were asked to count the number of comments that explicitly stated that categorizing individuals by race hurt those who were categorized, an explicit articulation of our competing hypothesis. Comments included:

"If you care that much about their race, you don't see them as a person."

and

"Looking at their race demeans them."

Inter-rater reliability was $86 \%$ with conflicts resolved through conversation. We hypothesized that White participants would make more strategically colorblind comments (meaning all three category codes) in the presence of non-Whites.

\section{Results}

Analyses reflect significant differences between the mixed- 
race and same-race groups (see Figure 1), such that Whites were more likely to indicate that paying attention to race was negative during mixed-race interactions than in all-White interactions, $t(26)=2.11, p<.05$. Similarly, Whites were more likely to state that they were uncomfortable categorizing people by race during mixed-race interactions than in all-White interactions, $t(26)=2.41, p<.05$. Finally, Whites were more likely to state that racial categorization causes people harm during mixed-race interactions than in all-White interactions, $t(26)=$ $2.12, p<.05$. Of note, no Black participants made such comments, meaning that only White participants did (in both the mixed-race and same-race groups).

\section{Discussion}

As predicted, Whites employed more strategic colorblindness in the presence of non-Whites than they did in all-White groups. Importantly to our hypotheses, they also indicated both more stereotype threat and more concern for the outcomes of nonWhites in the presence of non-Whites. This suggests that both concerns for the self and for others prompt the use of strategic colorblindness. To test these competing hypotheses directly, Study 2 manipulated stereotype threat and concerns with hurting non-Whites. Again, we expected that both the presence of stereotype threat and the likelihood that non-Whites would suffer from racial categorization would prompt increased reliance on strategic colorblindness.

\section{Study 2}

\section{Method}

\section{Participants and Design}

Participants were 91 White American undergraduates who were enrolled in introductory psychology courses at a large public university in the United States. They were randomly assigned to a 2 (Experience of stereotype threat: Present v. Absent $) \times 3$ (Harms of Racial Categorization: High v. Low v. Control) between subjects factorial design.

\section{Materials}

Stereotype Threat Scale. Participants filled out an explicit stereotype threat scale (STS; adapted from Goff et al., 2008) to measure the anxiety about being perceived as racist. The scale $(\alpha=.80)$ included 5 questions such as: "During this conversation, I worried that something I said might have been misinterpreted as prejudiced."

Strategic Colorblindness Scale. The authors developed the Strategic Colorblindness Scale (SCS, $\alpha=.91$ ) to measure participants' beliefs about the value of enacting colorblindness. Examples include: "Seeing people in terms of race is a significant hindrance to racial harmony", and "Ending racial categorization would create a more just society". The measure contains 11 items that participants respond to on a 7-point Likert scale (See appendix for full set of items). Higher scores on this measure indicate that one strongly believes that racial categorization has negative consequences.

\section{Procedure}

Participants arrived individually and were greeted by a White experimenter. After consenting to participate, participants were told that the purpose of the study was to examine interracial interactions. The experimenter then informed participants that they would engage a Black student from the university in a conversation about race and race relations. Participants were told that before having the interaction, the experimenters wanted to evaluate baseline racial attitudes. Participants were then given the Attitudes Towards Blacks scale (ATB; Brigham, 1993), a measure of explicit anti-Black prejudice. Participants were then given false feedback, such that half of the participants were told that they held low amounts of prejudice for this college and the other half told that they had high levels of prejudice for the college. Participants were then told that they had one more preliminary packet to fill out, during which they were given the second manipulation.

One third of participants were told that "people regularly categorize others based on their racial/ethnic affiliations. This racial categorization often contributes to various detrimental effects such as depression, lowered self-esteem, academic underachievement, and, in extreme cases, suicide." This was intended to persuade participants that racial categorization came with high costs - particularly for non-Whites. One third of participants were told that "people regularly categorize others based on their racial/ethnic affiliations. Very few serious detrimental effects have been found to be associated with this type

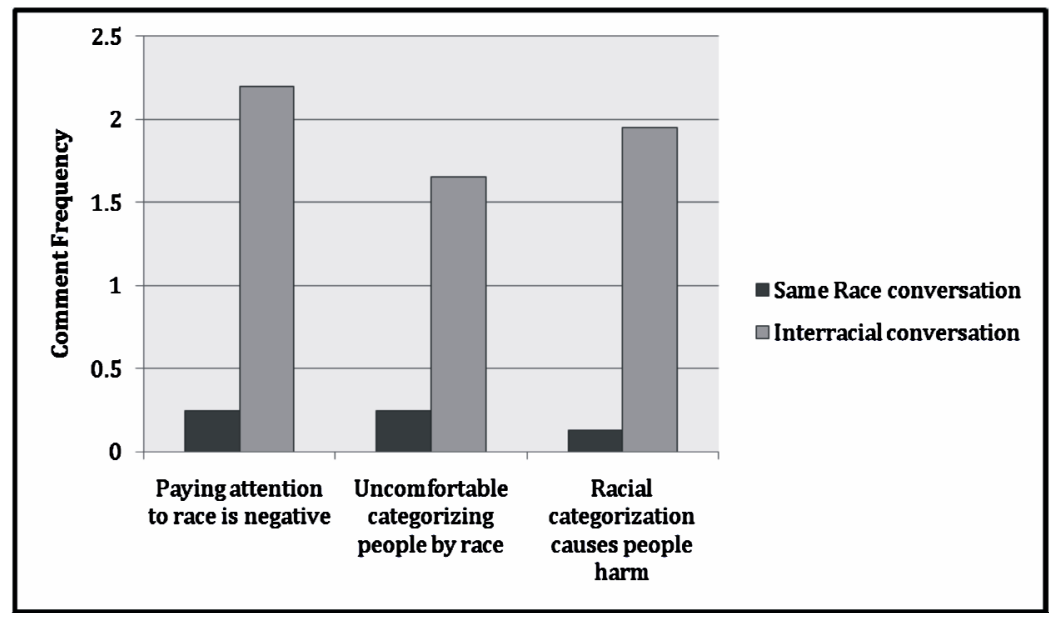

Figure 1.

Frequency of comments indicating strategic colorblindness. 
of racial categorization." This was intended to persuade participants that racial categorization came with low costs. Finally, in the control condition, participants were simply told that "people in certain environments tend to have similar political perspectives." Participants then completed our measures of stereotype threat and the devaluation of racial categorization. Participants were then told that the conversation would not actually occur and were fully debriefed.

Consistent with the comments observed in Study 1 indicating egalitarian motivations, we predicted that, absent the anxiety of appearing prejudiced, participants would employ strategic colorblindness, but only when informed that there were high costs to non-Whites as a result. However, we predicted that those who were concerned about appearing prejudiced would employ strategic colorblindness uniformly. That is, participants would employ strategic colorblindness even when given information that racial-awareness comes at no costs to non-Whites.

\section{Results}

Stereotype Threat Scale. Participants experienced more anxiety about appearing prejudiced after receiving feedback indicating high racial bias, relative to those told they held low racial bias, $F(1,85)=15.63, p<.001$. No other main effects or interactions were observed.

Strategic Colorblindness Scale. Analyses revealed a main effect of stereotype threat,such that participants under threat employed strategic colorblindness more than those that were not under threat, $F(1,85)=6.51, p=.01$. Analyses also revealed a main effect of harms due to racial categorization such that participants devalued racial categorization more when they were told it harmed others, $F(2,85)=3.07, p=.05$. These effects were qualified by the predicted two-way interaction: $F(2$, $85)=4.22, p<.05$ (see Figure 2).

Simple effects tests revealed that, absent stereotype threat, strategic colorblindness was employed more when participants believed race-consciousness harmed non-Whites than in each other condition, $F$ 's $(1,85)=10.50$, p's $<.005$. Simple effects tests also revealed that, for participants who received no infor-mation about racial harms, strategic colorblindness was en dorsedmore under threat than in the absence of threat, $F(1,85)$
$=7.21, p<.01$. The same pattern holds for participants who were told that racial categorization was not harmful, $F(1,85)=$ $6.77, p=.01$.

\section{Mediational Analyses}

We conducted mediational analyses to test whether the relationship between the feedback on the test of prejudice and strategic colorblindness was mediated by stereotype threat. We followed the mediation procedure outlined by Baron and Kenny (1986). The independent variable (feedback on test of prejudice type) significantly predicted the dependent variable (strategic colorblindness), $B=.26, t=2.50, p=.01$. The independent variable predicted the mediator variable (stereotype threat score), $B=.39, t=4.00, p<.001$. The mediator predicted the dependent variable when controlling for comment type, $B=$ $-.53, t=5.42, p<.001$. And lastly, controlling for the stereotype threat score, the independent variable no longer predicted the dependent variable, $B=.05$, n.s. (Sobel, $Z=3.2, p=.001$ ).

\section{Discussion}

The observed pattern of data reveals a clear relationship between the anxiety with being seen as prejudiced and strategic colorblindness. Specifically, the results suggest that when Whites experience stereotype threat, they employ strategic colorblindness even when being told that racial categorization has no impact on non-Whites. Study 2 also provides evidence that White's use of strategic colorblindness is closely related to their concerns about non-Whites. This provides the first direct test of the hypothesis that both egalitarian and self-protective motives influence Whites' responses to intergroup threat.

\section{General Discussion}

Across two studies, the present research finds consistent evidence that Whites' use of strategic colorblindness is motivated by both self-protective and egalitarian concerns - in both laboratory and field settings. Further, we have demonstrated that the use of colorblindness as a discourse strategy is not simply a function of demand characteristic in lab settings, but also occurs spontaneously in everyday conversation about race. This

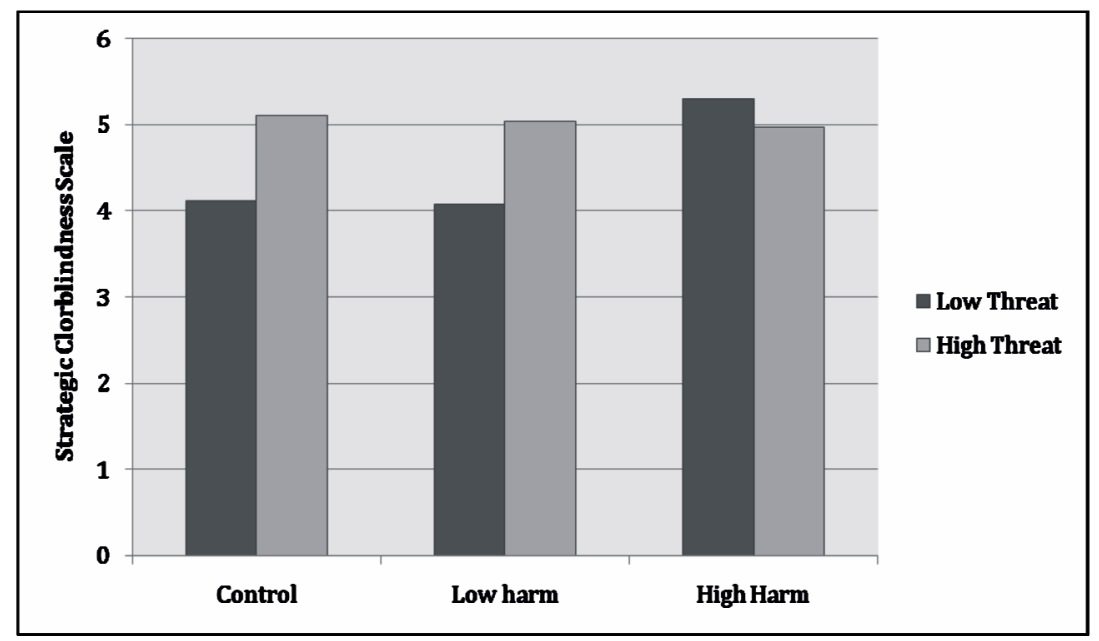

Figure 2.

Average ratings of the endorsement of strategic colorblindness according to the level of concern with appearing racist (threat) and perceived harms to non-Whites (harm). 
research differs from previous work that focused on self-protective motivations without directly testing the possibility for genuine egalitarian motives. The application of research on strategic colorblindness to actual interactions has the benefit of providing the literature with the ability to generalize beyond the lab and, simultaneously, to advance our theoretical understanding of Whites' motives for endorsing colorblindness, itself an important predictor of intergroup outcomes (Gutiérrez \& Unzueta, 2010).

Previous research has also demonstrated that adopting a colorblind ideology can lead to elevated racial prejudice among Whites' (Richeson \& Nussbaum, 2004; Morrison, Plaut, \& Ybarra, 2010). Future research, however, should examine whether this is the case regardless of the meaning of colorblindness. That is, it may be the case that egalitarian and hierarchy-enhancing interpretations of colorblindness lead to different intergroup outcomes, one increasing prejudice and intergroup tensions, the other decreasing them.

Regardless, the present research highlights the importance of translating research on intergroup relations to the worlds in which groups actual interact-and suggests that this can be done successfully. Doing so not only expands the boundary conditions for theories of intergroup interactions, but, in the case of the present research, provides information about the mechanisms that underlie those theories. In the specific example of strategic colorblindness, the present research suggests not only that the phenomena occurs naturally in the world, but that it can be motivated by nobler intentions than previously believed - a good thing for the future of intergroup interactions in the real world and the laboratory.

\section{REFERENCES}

Apfelbaum, E. P., Sommers, S. R., \& Norton, M. I. (2008). Seeing race and seeming racist? Evaluating strategic colorblindness in social interaction. Journal of Personality and Social Psychology, 95, 918-932. doi:10.1037/a0011990

Baron, R. M., \& Kenny, D. A. (1986). The moderator-mediator variable distinction in social psychological research: Conceptual, strategic, and statistical considerations. Journal of Personality and Social Psychology, 51, 1173-1182. doi:10.1037/0022-3514.51.6.1173

Brigham, J. C. (1993). College students' racial attitudes. Journal of Applied Social Psychology, 23, 1933-1967. doi:10.1111/j.1559-1816.1993.tb01074.x

Carson, C. (1987). Eyes on the prize: America's civil rights years: A reader and guide. New York: Penguin Books.

Dovidio, J. F., Kawakami, K., \& Gaertner, S. L. (2002). Implicit and explicit prejudice and interracial interaction. Journal of Personality and Social Psychology, 82, 62-68. doi:10.1037/0022-3514.82.1.62

Frantz, C. M., Cuddy, A. J. C., Burnett, M., Ray, H., \& Hart, A. (2004). A threat in the computer: The race Implicit Association Test as a stereotype threat experience. Personality and Social Psychology Bulletin, 30, 1611-1624. doi:10.1177/0146167204266650

Goff, P. A., Steele, C. M., \& Davies, P. G. (2008). The space between us: Stereotype threat and distance in interracial contexts. Journal of Personality and Social Psychology, 94, 91-107. doi:10.1037/0022-3514.94.1.91

Gutiérrez, A. S., \& Unzueta, M. M. (2010). The effect of interethnic ideologies on the perceptions of stereotypic vs. counter stereotypic minority targets. Journal of Experimental Social Psychology, 46, 743752. doi:10.1016/j.jesp.2010.03.010

Inzlicht, M., \& Ben-Zeev, T. (2000). A threatening intellectual environment: Why females are susceptible to experiencing problemsolving deficits in the presence of males. Psychological Science, 11, 365-371. doi:10.1111/1467-9280.00272

Knowles, E. D., Lowery, B. S., Chow, R. M., \& Hogan, C. M. (2009). On the malleability of ideology: Motivated construals of color-blindness. Journal of Personality and Social Psychology, 96, 857-869. doi: $10.1037 / \mathrm{a} 0013595$

Morrison, K. R., Plaut, V. C., \& Ybarra, O. (2010). Predicting whether multiculturalism positively or negatively influences White Americans' intergroup attitudes: The role of ethnic identification. Personality and Social Psychology Bulletin, 36, 1648-1661. doi: $10.1177 / 0146167210386118$

Richeson, J. A., Baird, A. A., Gordon, H. L., Heatherton, T. F., Wyland, C. L., Trawalter, S., \& Shelton, J. N. (2003). An fMRI investigation of the impact of interracial contact on executive function. Nature Neuroscience, 6, 1323-1328. doi:10.1038/nn1156

Richeson, J. A., \& Nussbaum, R. J. (2004). The impact of multiculturalism versus color-blindness on racial bias.Journal of Experimental Social Psychology, 40, 417-423. doi:10.1016/j.jesp.2003.09.002

Richeson, J. A., \& Shelton, J. N. (2007). Negotiating interracial interactions: Costs, consequences, and possibilities. Current Directions in Psychological Science, 16, 316-320. doi:10.1111/j.1467-8721.2007.00528.x

Schmader T. \& Johns M. (2003). Converging evidence that stereotype threat reduces working memory capacity. Journal of Personality and Social Psychology, 85, 440-452. doi:10.1037/0022-3514.85.3.440

Vorauer, J. D., Hunter, A. J., Main, K. J., \& Roy, S. A. (2000). Metastereotype activation: Evidence from indirect measures for specific evaluative concerns experienced by members of dominant groups in inter-group interactions. Journal of Personality and Social Psychology, 78, 690-707. doi:10.1037/0022-3514.78.4.690

Vorauer, J. D., Main, K. G., \& O'Connell, G. B. (1998). How do individuals expect to be viewed by members of lower status groups: Content and implications of meta-stereotypes. Journal of Personality and Social Psychology, 75, 917-937. doi:10.1037/0022-3514.75.4.917

ality.

6. Seeing people in terms of race is an injustice.

7. Ending racial categorization would create a more just society.

8. Seeing people in terms of race leads to stereotyping.

9. Racism and prejudice are products of racial categorization.

10. Recognizing racial affiliations prevents the United States from moving towards a more socially just society.

11. Seeing people in terms of race is a significant hindrance to racial harmony. 